\title{
Open access, open data and peer review
}

Jernej Ule 1,2,3

Correspondence: jernej.ule@crick.ac. uk

${ }^{1}$ The Francis Crick Institute, 1 Midland Road, London NW1 1AT, UK

2Department of Neuromuscular Diseases, UCL Queen Square Institute of Neurology, Queen Square, London WC1N 3BG, UK Full list of author information is available at the end of the article

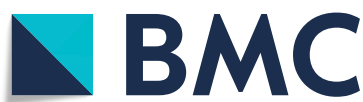

- The Author(s). 2020 Open Access This article is licensed under a Creative Commons Attribution 4.0 International License, which permits use, sharing, adaptation, distribution and reproduction in any medium or format, as long as you give appropriate credit to the original author(s) and the source, provide a link to the Creative Commons licence, and indicate if changes were made. The images or other third party material in this article are included in the article's Creative Commons licence, unless indicated otherwise in a credit line to the material. If material is not included in the article's Creative Commons licence and your intended use is not permitted by statutory regulation or exceeds the permitted use, you will need to obtain permission directly from the copyright holder. To view a copy of this licence, visit http://creativecommons.org/licenses/by/4.0/. The Creative Commons Public Domain Dedication waiver (http://creativecommons.org/publicdomain/zero/1.0/) applies to the data made available in this article, unless otherwise stated in a credit line to the data. 
retain a diversity of cost-effective publishing options [7]. It has also been proposed that the costs of open access could be brought down if work of professional editors was largely replaced by academic editors, pioneered by journals such as eLife. This works as an excellent complementary system, but I wonder if we scientists could find sufficient time to act as editors for most scientific literature. The most brilliant scientists can be the worst editors if they have little time to read or engage with a paper, and we scientists have networks of colleagues and other biases of our own that are hard to avoid. The other alternative would be a system of public reviews such as PubPeer, twitter threads and science blogs, integrated with machine learning that would collate all information to rank the impact of papers. Again, while this is already developing into a valuable and ongoing complement that is bound to grow, it lacks moderation by editors and could bias towards those who invest more effort into networks or language of self-promotion as a way to stand out of the crowd if it were to replace peer review. Indeed, learning from the rapid rise of social networks over the last decade and their suddenly dominant role in news distribution demonstrates their potential for skewing the conversation into extremes.

A compromise that would satisfy most concerns has recently been proposed as a 'Plan $U$ ', in which funders require that grantees deposit manuscripts on a preprint server such as bioRxiv under a Creative Commons Attribution licence (CC BY) before submission and peer review in any type of journal [8]. While this sounds like a reasonable option, it leaves the question of open data unresolved. Currently, bioRxiv submissions are not obliged to provide the data that accompany the manuscript, so the underlying data are most often provided only as part of the final publication. This is creating a system where one can plant a flag in a research field without the need to provide the associated data that would be essential to evaluate the validity of conclusions. A further obstacle that is hampering our field is the rapid evolution of methods, data types and annotations, which are hard to properly curate when submitting to generic repositories such as GEO. For example, the study of protein-RNA interactions through a method called CLIP has already led to over 30 variant methods that differ aspects such as barcoding and crosslink site definition, and therefore, more specialised repositories are needed that enable methodspecific annotation, quality control and analysis and provide both raw and processed data along with various visualisation tools [9]. Initiatives to support the development of new biomedical data resources are well placed to tackle such challenges [10], and publishers are looking for business models that could link new types of data repositories to the review process and to final publications [4]. It would make a great difference to reviewers to be able to explore processed data through standardised online platforms that provide method-specific metrics and visualisation.

In conclusion, the innovations in science publishing are taking place at multiple levels: open access to publications, presentation of data in an accessible manner, transparent and unbiased systems for evaluating scientific output, and reasonable costs of publishing, including in the top tier journals. It will be exciting to watch as new innovations emerge at all of these levels and to see journals such as Genome Biology find ways to link open access, new data curation and repository innovations with high-quality peer review and reasonable publication charges. 
Author's contributions

The author read and approved the final manuscript.

\section{Competing interest}

The author declares that he has no competing interests.

\section{Author details}

${ }^{1}$ The Francis Crick Institute, 1 Midland Road, London NW1 1AT, UK. ²Department of Neuromuscular Diseases, UCL Queen Square Institute of Neurology, Queen Square, London WC1N 3BG, UK. ${ }^{3}$ National Institute of Chemistry, Hajdrihova 19, SI-1001 Ljubljana, Slovenia.

Published online: 04 May 2020

\section{References}

1. Coalition S. Plan S. Making full and immediate open access a reality. 2019. Downloaded at)([April 11, 2019]) https:// www.coalition-s.org/about/Niew.in.Article.

2. Else H. High-profile subscription journals critique Plan S. Nature [Internet]: Nature Publishing Group; 2019. [cited 2020 Mar 11]; Available from: https://www.nature.com/articles/d41586-019-00596-x.

3. Debat H, Babini D. Plan S in Latin America: a precautionary note [Internet]. PeerJ Preprints. 2019; Jul. Report No.: e27834v2. Available from: https://peerj.com/preprints/27834v2/.

4. Posada A, Chen G. Inequality in knowledge production: the integration of academic infrastructure by big publishers [Internet]: 22nd International Conference on Electronic Publishing; 2018. Available from: https://doi.org/10.4000/ proceedings.elpub.2018.30.

5. Swart M, Profile V my C. Impact of Plan S on Chemistry research in Europe [Internet]. [cited 2020 Mar 11]. Available from: http://trends-in-science.blogspot.com/2018/09/impact-of-plan-s-on-chemistry-research.html.

6. McNutt M. Opinion: "Plan S" falls short for society publishers-and for the researchers they serve. Proc Natl Acad Sci U S A. 2019;116:2400-3.

7. Kiley R, Smits R-J. cOAlition S: response to PNAS. Proc Natl Acad Sci U S A. 2019:116(13):5859-60. https://www.ncbi.nlm. nih.gov/pubmed/?term=30833412.

8. Sever R, Eisen M, Inglis J. Plan U: universal access to scientific and medical research via funder preprint mandates. PLoS Biol. 2019;17:e3000273.

9. Chakrabarti AM, Haberman N, Praznik A, Luscombe NM, Ule J. Data science issues in studying protein-RNA interactions with CLIP technologies. Annu Rev Biomed Data Sci. 2018;1:235-61.

10. Biomedical resource grants [Internet]. [cited 2020 Mar 11]. Available from: https://wellcome.ac.uk/funding/schemes/ biomedical-resource-grants.

\section{Publisher's Note}

Springer Nature remains neutral with regard to jurisdictional claims in published maps and institutional affiliations. 